CONFERENCES КОНФЕРЕНЦИИ

Conference Report

\title{
The 12th International Conference on (Im)Politeness (Cambridge, Anglia Ruskin University 17-19 July, 2019): A Report
}

\author{
Vahid Parvaresh
}

Anglia Ruskin University, UK

East Rd, Cambridge CB1 1PT

For citation:

Parvaresh, Vahid (2019). The 12th International Conference on (Im)Politeness (Cambridge, Anglia Ruskin University 17-19 July, 2019): A Report. Russian Journal of Linguistics, 23 (4), 1122-1127. doi: 10.22363/2312-9182-2019-23-4-1122-1127.

\section{2-я Международная конференция по (не)вежливости (Кембридж, Университет Англия Раскин, 17-19 июля 2019 г.)}

Вахид Парвареш

Университет Англия Раскин, Кембридж, Великобритания

East Rd, Cambridge CB1 1PT

Для цитирования:

Parvaresh, Vahid (2019). The 12th International Conference on (Im)Politeness (Cambridge, Anglia Ruskin University 17-19 July, 2019): A Report. Russian Journal of Linguistics, 23 (4), 1122-1127. doi: 10.22363/2312-9182-2019-23-4-1122-1127.

It has now become widely accepted that human interaction is heavily dependent on norms, obligations, values and (tacitly held) assumptions. Given the fact that we live in different lingua-cultures, many linguists, sociologists, anthropologists, etc. have set themselves the task of closely examining these norms. In this respect, an important question would be, 'what constitutes (im)politeness?' As a direct consequence of this, 
the study of (im)politeness has recently become so popular in academia that there is a great need for further synergy in this field.

In response to the above need and given the 'elusive' nature of (im)politeness (Culpeper, 2013, p. 3), the School of Humanities and Social Sciences at Anglia Ruskin University organised and hosted the 12th International Conference on (Im)politeness at its Cambridge Campus from 17-19 July 2019, continuing the tradition of successful conferences organised under the aegis of the Linguistic Politeness Research Group. Given the fact that those who study (im)politeness do not always adopt mainstream approaches to the topic, but rather are motivated to use more innovative theoretical and analytical perspectives, it was decided to organise the conference under the general theme of 'Within and Beyond Mainstream Approaches to (Im)politeness'.

In general, the many diverse papers which were received are testament to the fact that (im)politeness studies is undoubtedly an active line of inquiry which is being pursued via a variety of novel theoretical and analytical approaches. As chair of the conference, and having read each paper's abstract as well as personally attending many of the presentations, I observed the following developments in (im)politeness studies:

a. It appears that the study of (im)politeness, as found in historical data, has become an increasingly popular trend. This is a particularly welcome development because it enables researchers to make more informed comparisons between modern day norms and obligations, as opposed to those practiced in the past. Also, reconstructing the past is an endeavour that many scholars, in different fields of inquiry, have undertaken over the years. The (im)politeness researcher's take on the topic is a welcome addition to what is already known.

b. Many of the contributors examined online data, particularly data pertaining to the use of language on social media (e.g. Twitter). Given the fact that we would appear to be currently living in what Yus $(2019$, p. 1) calls the fifth phase of the Net, where "there is a presumption of physical-virtual congruence, since users do not turn into different people in either of the environments (offline/ online)", the use of such data is welcome. Furthermore, some of the papers revealed that new platforms (e.g. Instagram, YouTube, etc.) provide their users with new affordances, thus enabling researchers to have unprecedented access to the interactional achievements of users by investigating their evaluative language (i.e. meta-language). This tendency has given rise to some interesting studies on the topic.

c. Another important insight revealed by a number of papers was that the study of aggressive language can reveal a great deal about human interaction and the corresponding hidden social values. As some of the studies revealed, the use of aggressive language has been increasing, particularly on the Internet, which is why its investigation has become popular. While there is great potential in all the topics discussed during the conference, given the importance and urgency of such issues as cyberbullying and trolling, there appears to be a need for further investigation of the language of cyberbullying.

d. Another fascinating aspect of the conference was the contribution made by some of the studies to conceptualising morality, an important feature of human interaction. Of course, the question of what is right or wrong has always arisen (see 
Haidt, 2012); however, the study of the intersection between morality and impolite and aggressive behaviour is more recent, and has great potential to advance our understanding of the topic (Parvaresh, 2019).

e. In the case of impolite language, as many of the authors stipulated in their presentations, a clear distinction should always be made between the speaker and the hearer, or rather between causing offence (e.g. Bousfield, 2008; Culpeper, 2011) and taking offence (e.g. Haugh, 2015; Tayebi, 2016; see also Haugh \& Sinkeviciute, 2019). The latter point pertains to the ever-increasing importance being placed on (im)politeness as a means of evaluation (Kádár \& Haugh, 2013).

f. As many of the papers pointed out, the notion of (im)politeness continues to be investigated in a variety of discourse domains, including, amongst others, political language. This is understandable when it is considered that, with the current dramatic increase in the use of social media, there are few boundaries between politicians and ordinary people, hence resulting in the ubiquitous use of polarised language. Indeed the study of such polarised language can offer fresh insight into (im)politeness studies.

g. The investigation of the language used in conflict, defined as those interactive situations which are processed as "manifested in incompatibility, disagreement, or difference within or between social entities (i.e., individual, group, organization, etc.)" (Rahim, 2017, p. 370; cf. Kelly et al., 2019), has been attracting the attention of many researchers. This is understandable and very much welcome given the fact that conflict can potentially lead to, amongst other things, the use of impolite and/or aggressive language (see Kádár et al., 2019, for a theoretical discussion).

h. Speech acts (e.g. apology, refusal) continue to attract the attention of many researchers, including both established academics as well as research students, particularly when it comes to second language learning/acquisition. This is understandable because speech acts are suitable for comparative purposes, thus enabling researchers to compare two languages more conveniently. Of course, this line of research has, over the years, contributed a great deal to our understanding of (im)polite norms, as revealed by the many speech acts investigated. Even so, as was emphasised in one of the conference sessions, there appears to be a need for such speech act focused comparative studies to adopt more innovative frameworks, i.e. ones which enable researchers to take account of the actual dynamics of the situation. Adopting the notion of pragmeme, i.e. situational prototypes (e.g. Mey, 2001; Parvaresh \& Capone, 2017) might be a solution.

i. Given the increase in the use of online data for research projects on (im)politeness, the issue of research ethics requires particular attention. During the $12^{\text {th }}$ International Conference on (Im)Politeness I observed, on many occasions, the admirable practice of highlighting to the audience the ethical considerations and risks that were involved in data collection and how each author managed these risks. As Locher and Bolander (2019, p. 88) note, holding an "ethics-related conversation" should ideally be encouraged more, an endeavour which can "enhance the likelihood" that we "learn from best practices". 
The conference also featured four plenary speakers, and on the first day of the conference Juliane House and Daniel Kádár performed this role. In their separate, but related, talks, Juliane and Daniel shared with the delegates the findings of their project, i.e. the use of what they termed 'Ritual Frame Indicating Expressions' (RFIEs). While Juliane's talk focused on how examples of these RFIEs are generally translated across languages, Daniel explored the use of some of these RFIEs in different corpora. Overall, Juliane and Daniel argued that, to compare languages in terms of (im)politeness, one should focus on comparable aspects of language and, according to the authors, RFIEs are one of the best candidates for this purpose as they are linked with the 'rights and obligations' which are at the heart of any interaction.

On the second day, Jonathan Culpeper conducted the plenary talk. He first provided the audience with some crucial information regarding the origins of (im)politeness studies. As Jonathan claimed, rather surprisingly, politeness studies date back to 1558 when Giovanni della Casa's Il Galateo was published. According to Jonathan, the book could be cautiously considered to be a "precursor" to some of today's classic politeness models. Jonathan also argued that politeness studies do not necessarily have a 'standard' theory or set of standard theories. Hence, as Jonathan suggests, despite its well-discussed flaws, Brown and Levinson's (1987) politeness theory can still be used provided it is:

— "used critically and sensitively"

— "supplemented by other notions"

As far as data and methodology are concerned, Jonathan predicted that the dominance of qualitative methods is unlikely to change in the future, but a more systematic use of corpus and quantitative methods is likely to become more popular.

The final plenary talk was given by Andreas H. Jucker who explored the rise and fall of what he referred to as 'non-imposition politeness', which, in principle, "consists of the strategies that give the addressee a choice" (Jucker, 2012, p. 425). These strategies serve to highlight 'noncoerciveness', and thus help the speaker not to, or at least pretend not to, "intrude on the addressee's wish to remain free from imposition, as for instance in the polite request, 'Could you, please, open the window?'” (Jucker, 2012, p. 425). Adopting a genre-based methodology with an inherently bottom-up approach, Andreas's talk painted a very illuminating picture of how these non-imposition politeness forms, exemplified by request forms, were used throughout the twentieth century. Andreas explained how the study of non-imposition politeness increased rapidly during the second half of the twentieth century, but has since somewhat declined in recent years.

The $12^{\text {th }}$ International Conference on (Im)Politeness also marked the launch of a new journal, namely Contrastive Pragmatics - A Cross-Disciplinary Journal. Published by Brill Publishers and co-edited by Karin Aijmer, Juliane House, Daniel Kádár and Hong Liu, the journal, as the name suggests, seeks to attract contributions that compare and contrast languages used within different lingua-cultures.

All in all, I believe that the $12^{\text {th }}$ International Conference on (Im)Politeness was successful in achieving its aims. It served as a friendly venue for the discussion of recent 
findings in this field. A wide range of topics, data-sets and languages were discussed. The question and answer sessions were critical but constructive, enabling both the audience and researchers to engage in dialogue, which was further testament to the fact that (im)politeness research "is a dynamic and growing field" (Culpeper et al., 2017, p. 7).

(C) Vahid Parvaresh, 2019 cc) creative

https://creativecommons.org/licenses/by/4.0/

\section{REFERENCES}

Bousfield, Derek (2008). Impoliteness in Interaction. Amsterdam: John Benjamins.

Brown, Penelope \& Stephen C. Levinson (1987). Politeness: Some Universals in Language Usage. Cambridge: Cambridge University Press.

Culpeper, Jonathan. (2011). Impoliteness: Using Language to Cause Offence. Cambridge: Cambridge University Press.

Culpeper, Jonathan (2013). Impoliteness: Questions and answers. In Denis Jamet \& Manuel Jobert (eds.), Aspects of Linguistic Impoliteness (pp. 2-15). Newcastle upon Tyne: Cambridge Scholars Publishing.

Culpeper, Jonathan, Michael Haugh \& Daniel Z. Kádár (2017). Introduction. In Jonathan Culpeper, Michael Haugh \& Daniel Z. Kádár (eds.), The Palgrave Handbook of Linguistic (Im)Politeness (pp. 1-8). London: Palgrave Macmillan.

Haidt, Jonathan (2012). The Righteous Mind: Why Good People Are Divided by Politics and Religion. New York: Vintage.

Haugh, Michael (2015). Impoliteness and taking offence in initial interactions. Journal of Pragmatics, $86,36-42$.

Haugh, Michael \& Valeria Sinkeviciute (2019). Offence and conflict talk. In Matthew Evans, Lesley Jeffries \& Jim O'Driscoll (eds.), The Routledge Handbook of Language in Conflict (pp. 196214) Abingdon, Oxon: Routledge.

Jucker, Andreas H. (2012). Changes in politeness cultures. In Terttu Nevalainen \& Elizabeth Closs Traugott (eds.). Handbook of the History of English. Oxford: Oxford University Press.

Kádár, Daniel. Z. \& Michael Haugh (2013). Understanding Politeness. Cambridge: Cambridge University Press.

Kádár, Daniel Z., Vahid Parvaresh \& Puyu Ning (2019). Morality, moral order, and language conflict and aggression: A position paper. Journal of Language Aggression and Conflict, 7(1), 6-31.

Kelly, Michael, Hilary Footitt \& Myriam Salama-Carr (eds.). (2019). The Palgrave Handbook of Languages and Conflict. London: Palgrave Macmillan.

Locher, Miriam A. \& Brook Bolander (2019). Ethics in pragmatics. Journal of Pragmatics, 145, $83-90$.

Mey, Jacob. (2001). Pragmatics: An Introduction (2nd edn). Oxford: Blackwell.

Parvaresh, Vahid. (2019). Moral impoliteness. Journal of Language Aggression and Conflict, 7 (1), $79-104$.

Parvaresh, Vahid \& Alessandro Capone (eds.). (2017). The Pragmeme of Accommodation: The Case of Interaction around the Event of Death. Cham, Switzerland: Springer.

Rahim, Afzalur (2017). Managing Conflict in Organisations. London: Routledge. 
Tayebi, Tahmineh (2016). Why do people take offence? Exploring the underlying expectations. Journal of Pragmatics, 101, 1-17.

Yus, Francisco (2019). An outline of some future research issues for internet pragmatics. Internet Pragmatics, 2(1), 1-33.

\section{Bionote:}

VAHID PARVARESH is Senior Lecturer in the School of Humanities and Social Sciences at Anglia Ruskin University, UK. His areas of interest include pragmatics theory, aggressive language as well as vague language studies. Vahid has published in various leading journals of the field, including Journal of Pragmatics, International Review of Pragmatic, Corpus Pragmatics and Journal of Language Aggression and Conflict, among others. His most recent book, Elastic Language in Persuasion and Comforting: A Cross-Cultural Perspective (co-authored with Grace Zhang), has just been published by Palgrave Macmillan.

Contact information: Vahid.Parvaresh@anglia.ac.uk

\section{Сведения об авторе:}

ВАХИД ПАРВАРЕШ - доцент Школы гуманитарных и социальных наук Университета Англия Раскин, Великобритания. Сфера его интересов включает теорию прагматики и языковую агрессию. Публикуется в ведущих журналах в этой области, среди которых - Journal of Pragmatics, International Review of Pragmatic, Corpus Pragmatics, Journal of Language Aggression and Conflict. В 2019 г. в издательстве Palgrave Macmillan вышла его книга Elastic Language in Persuasion and Comforting: A Cross-Cultural Perspective (в соавторстве с Грейс Чжан).

Контактная информация: Vahid.Parvaresh@anglia.ac.uk 